\title{
IMPLEMENTASI CORPORATE SOCIAL RESPONSIBILITY PT. ASTRA INTERNASIONAL MELALUI PROGRAM LINGKUNGAN KAMPUNG BERSERI
}

\author{
Elsa Nurlatifa ${ }^{1}$, Kokom Komariah ${ }^{2}$, Aat Ruchiat Nugraha ${ }^{3}$ \\ Universitas Padjadjaran, Bandung, Indonesia
}

\begin{abstract}
ABSTRAK
Corporate Social Responsibility (CSR) merupakan komitmen perusahaan secara sukarela untuk meningkatkan kesejahteraan komunitas. Program CSR PT. PT. Astra International Tbk. International Tbk., salah satunya adalah Kampung Kampung Berseri PT. Astra International Tbk. (KBA). Program KBA berkaitan dengan empat pilar perusahaan, yaitu pendidikan, kesehatan, pembinaan Usaha Kecil Menengah (UKM), dan lingkungan. Di dalam pelaksanaannya, perusahaan bekerja sama dengan warga masyarakat sekitar perusahaan agar terbentuk program berkelanjutan. Penelitian ini bertujuan untuk mengetahui bagaimana divisi CSR dan tim Kampung Berseri PT. Astra International Tbk. melakukan tahapan CSR, yaitu perencanaan, implementasi, dan evaluasi program Kampung Berseri PT. Astra International Tbk.. Dengan menggunakan paradigma positivisme serta metode deskriptif., hasil penelitian menunjukkan bahwa : pertama, pada tahap perencanaan, yakni penetapan tujuan CSR Kampung Berseri PT. Astra International Tbk. mengacu pada visi dan misi utama perusahaan, penetapan target sasaran dengan cara social mapping dan membentuk tim khusus pada masing-masing wilayah. Kedua, pada tahap implementasi SCR Kampung Berseri PT. Astra International Tbk., PT. PT. Astra International Tbk. Internasional Tbk. melaksanakannya dengan panduan PT. Astra International Tbk. Friendly Company dan strategi sentralisasi serta self-managing. Terdapat kendala dalam pendampingan SDM. Ketiga, tahap evaluasi dilakukan setiap satu semester sekali dengan cara monitoring dan progress report melalui lembar balik, yang juga melibatkan pihak internal dan eksternal perusahaan.
\end{abstract}

Kata-kata Kunci: Corporate Social Responsibility, Implementasi, Kampung Berseri, Program, PT. Astra International Tbk.

\section{CORPORATE SOCIAL RESPONSIBILITY IMPLEMENTATION PT ASTRA INTERNATIONAL TBK. THROUGH THE KAMPUNG BERSERI}

\begin{abstract}
Corporate Social Responsibility (CSR) is the company's voluntary commitment to improve community welfare. CSR programs of PT. PT. Astra International Tbk. International Tbk., one of them is Kampung Berseri PT. Astra International Tbk. (KBA). The KBA program is related to the four pillars of the company, namely education, health, fostering Small and Medium Enterprises (SMEs), and the environment. In its implementation, the company cooperates with community members around the company to create a sustainable program. This study aims to find out how the CSR division and the Kampung Berseri PT. Astra International Tbk. team carry out CSR stages, namely planning, implementation, and evaluation of the Kampung Berseri PT. Astra International Tbk. program. By using the positivism paradigm and the descriptive method, the results of the study aims that: first, at the planning stage, the determination of
\end{abstract}


Kampung Berseri PT. Astra International Tbk.'s CSR goals refers to the company's main vision and mission, setting target targets by social mapping and forming a special team on each region. Second, at the stage of the implementation of the Kampung Berseri PT. Astra International Tbk. SCR, PT. PT. Astra International Tbk. International Tbk. implement it with the PT. Astra International Tbk. Friendly Company guidelines and centralized and self-managing strategies. There are obstacles in HR assistance. Third, the evaluation phase is conducted once every semester by monitoring and progress reports through flipchart, which also involves internal and external parties of the company.

Keywords: Corporate social responsibilty, implementation, Kampung Berseri, PT. Astra International Tbk

\section{PENDAHULUAN}

Sejak tahun 2007 peraturan tentang Corporate Social Responsibility (CSR) ditetapkan oleh pemerintah Indonesia sebagai hukum yang mengikat, maka setiap perusahaan wajib melaksanakan CSR atau dalam bahasa Indonesia dikenal dengan Tanggung Jawab Sosial Perusahaan. Akan tetapi seiring berjalannya waktu, tanggapan perusahaan sekarang ini tentang kegiatan CSR tidak hanya sebatas normatif saja tetapi sudah merupakan komitmen perusahaan secara sukarela untuk meningkatkan kesejahteraan komunitas, dan bukan merupakan aktifitas bisnis yang diwajibkan oleh hukum dan perundang - undangan seperti halnya kewajiban untuk membayar pajak atau kepatuhan perusahaan terhadap undang - undang ketenagakerjaan.

Pengertian CSR semacam itu, dapat disampaikan Rahmayani dan Silvana, CSR adalah merupakan komitmen perusahaan untuk meminimalisir dampak negatif dengan memaksimalkan kontribusi positif kepada seluruh stakeholders dalam aspek ekonomi, sosial, dan lingkungan untuk memperoleh pembangunan berkelanjutan (Rahmayani \& Silvana, 2018).

Temuan hasil riset ilmiah terkait akan peran dan pentingnya kegiatan SCR menunjukkan pengaruh yang positif baik bagi perusahaannya mau pun bagi khalayak sasaran atau stakeholdernya, diantaranya sebagaimana hasil evaluasi dari kegiatan Digital Learning CSR Telkom telah mampu mempengaruhi loyalitas dan reputasi perusahaan sebesar $70 \%$. Sebagai dampaknya masyarakat menganjurkan untuk menggunakan produk Telkom kepada calon konsumen lainnya (Andriana, Novianti, Priyatna, \& Rejeki), 2019).

Aktivitas CSR biasanya diarahkan pada potensi sumber daya alam yang telah dimiliki masyakat sekitar. 
Perusahaan tinggal menggali potensi yang ada, lalu mengembangkannya misalnya dengan cara memberikan pelatihan atau pembinaan, yang pada akhirnya program CSR perusahaan dijadikan sebagai sokoguru dalam mencapai tingkat kesejahteraan hidupnya. Dengan kata lain, perusahaan telah melakukan pemetaan potensi sosial yang dimiliki oleh masyarakat dalam pelaksanaan program CSR tersebut agar dapat memberdayakan masyarakat secara mandiri (Nugraha, Sumartias, Novianti, \& Komariah, 2015)

PT. Astra Internasional Tbk. adalah salah satu perusahaan yang melaksanakan kegiatan CSR yang dilakukan bertujuan untuk meningkatkan citra positif perusahaan dan memberikan pendekatan dengan lingkungan masyarakat. Nama program CSR tersebut adalah Kampung Berseri PT. Astra International Tbk.. Dalam perencanaannya, Kampung Berseri PT. Astra International Tbk. atau yang lebih dikenal dengan KBA mengacu pada empat pilar perusahaan, sebagai sinergitas dari visi dan misi perusahaan.

Program KBA dilakukan dengan cara bekerja sama dengan masyarakat dan tokoh masyarakat. Hal tersebut diupayakan agar terbentuk hubungan yang berkelanjutan antara PT. Astra International Tbk., dengan publik. Setelah diadakan komunikasi dengan warga terhadap program yang akan dilaksanakan, perusahaan segera mengimplementasikan program CSR tersebut yang mencakup 4 pilar di bidang Pendidikan, Kesehatan, Lingkungan, dan UMKM yang berpedoman pada AFC (PT. Astra International Tbk. Friendly Company).

Dalam pelaksanaannya, ada satu pilar yaitu lingkungan yang implementasinya mengalami ketidaksesuaian antara program dengan partisipasi warga secara berkelanjutan. Sebagai program regional, konsep Kampung Berseri Astra dan sumber daya manusia diturunkan langsung dari pusat. Namun sumber daya manusia hanya disertakan di awal kegiatan dan tidak berkelanjutan. Hal ini yang menyebabkan program 4 pilar Kampung Berseri A masih mengalami kekurangan sebagai satu sinergitas CSR. Melihat dari kekurangan tersebut, maka diperlukan need assesment sebagai tahapan untuk melihat pola CSR. Tahapan ini dilakukan untuk melihat lebih rinci bagaimana proses perencanaan, implementasi, dan evaluasi yang dilakukan oleh KBA. Sehingga dalam proses terbentuknya 
suatu program, dapat dilihat lebih jelas hal apa saja yang menjadi kekurangan dalam implementasinya.

CSR membutuhkan perumusan yang jelas, baik materi, strategi, sasaran, penelitian pemangku kepentingan, anggaran yang dibutuhkan. Untuk itu, butuh kajian mendalam dan berkelanjutan, khususnya dalam menentukan isi dan sasaran agar memiliki daya dukung dalam pembangunan berkelanjutan, agar meningkatkan pemberdayaan pada para pemangku kepentingan. Kualitas perencanaan praktik $C S R$ tergantung pada analisis perusahaan terhadap lingkungan dan sosial. Tanggung jawab perusahaan terhadap masyarakat dan lingkungan diwujudkan dalam bentuk perilaku transparan dan etis yang sejalan dengan pembangunan berkelanjutan, serta sejalan dengan hukum yang ditetapkan dengan norma - norma perilaku internasional. Yang pada akhirnya akan terintegrasi secara menyeluruh (Prastowo \& Huda, 2011).

Nor Hadi merumuskan tahapan CSR dari perencanaan, implementasi, dan evaluasi. Dalam perencanaan meliputi Penetapan visi yang sinergis dengan visi perusahaan. Visi memberikan arahan bagi para pihak pengelola perusahaan untuk menentukan code of conduct perusahaan, agar sejalan dengan nilai masyarakat. Kemudian penetapan misi merupakan penjabaran secara lebih operasional dari visi. Sehingga, misi CSR merupakan wahana untuk menginformasikan siapa perusahaan, landasan filosofis perusahaan, inti atau garis aktivitas perusahaan dimata stakeholder (Hadi, 2011). Penetapan tujuan, juga merumuskan apa yang akan diselesaikan oleh perusahaan dalam keberpihakan terhadap para pemangku kepentingan dan kapan akan diselesaikan, serta mengukur secara akurat kegiatan dilakukan. Serta melalui penetapan target, para pelaksana tanggung jawab sosial, memiliki patokan dalam melaksanakan program bersangkutan (Hadi, 2011).

Kebijakan merupakan pedoman umum sebagai acuan pelaksanaan program $C S R$, serta yang akan menjadi warna orientasi satu program. Ada tiga prinsip SCR yang perlu dipertimbangkan perusahaan yaitu : Pertama, perusahaan mengembangkan good corporate governance (GCG). Perusahaan bertanggungjawab pada dampak eksternal yang pada akhirnya mengarah pada pertanggungjawaban sosial 
perusahaan untuk masalah-masalah keterbukaan informasi, akuntabilitas, kemandirian, kesetaraan, dan kewajaran. Kedua, mencapai standar umum perilaku perusahaan dalam Caux Principles for Business. Ini merupakan standar umum perilaku perusahaan secara etis dan bertanggungjawab yang mencakup penghormatan terhadap stakeholder di atas shareholder. Ketiga, mengacu pada United Nation Global Compact yang merupakan standar corporate social responsibility yang dipelopori $\mathrm{PBB}$ yang mencakup empat wilayah utama, yaitu HAM, tenaga kerja, lingkungan, dan anti korupsi (Setianto, 2012)

Hal demikian dalam menetapkan strategi implementasi CSR memiliki ketergantungan arah mana kebijakan CSR dilakukan. Strategi merupakan sarana untuk menjabarkan visi, misi, dan kebijakan $C S R$ yang akan dipraktikkan (Hadi, 2011). Perusahaan juga melakukan CSR didasarkan pada motif dan merancang struktur organisasi, terutama pada motif ekonomi. Mereka melakukan CSR dengan memperhatikan feedback yang diperoleh dibalik sosial yang dilakukan (Solihin, 2009).

Rancangan program harus dilakukan karena merupakan tindakan yang dimaksudkan guna meminimlisir kekurangefektifan praktik $C S R$ yaitu dengan cara mengidentifikasi permasalahan yang ada, dan menjadi kebutuhan daripada para stakeholdernya.

Mempersiapan sumber daya manusia yang numpuni menjadi proses yang penting, karena dapat menentukan kuantitas dan kualitas dari keberhasilan pelaksanaan CSR.. Selain perusahaan menyediakan sumber daya manusia dalam melaksanakan CSR, perusahaan juga dapat melakukan kolaborasi dengan pihak eksternal dan para pemerhati masalah sosial dan lingkungan, seperti LSM, lembaga pemerintah, non pemerintah, media massa, institusi pendidikan, asosiasi profesi dan sejenisnya. Model atau pola semacam ini sebagaimana dijelaskan Saidi dan Abidin adalah model bermitra dengan pihak lain (Setianto, 2012)

Penentuan sumber dana juga dilakukan menurut Undang - undang No. 40 tahun 2007 yang menyatakan bahwa perusahaan yang operasinya bersentuhan eksploitasi sumber daya alam harus menyisihkan sampai tiga persen $(3 \%)$ dari keuntungan untuk kegiatan bina lingkungan dan kemitraan. 
Implementasi CSR merupakan tahap program CSR. Dalam penerapannya membutuhkan iklim organisasi yang saling percaya dan kondusif, sehingga memunculkan motivasi dan komitmen karyawan pelaksana. Dalam implementasinya, terbagi menjadi dua yaitu mengimplementasikan program CSR KBA dan mengimplementasikan manajemen CSR KBA (Hadi, 2011). Implementasi program $C S R$ berarti merencanakan implementasi pelaksanaan tanggung jawab lapangan. Terdapat berbagai pendekatan yang dapat dijadikan pijakan dalam mengimplementasikan praktik CSR, antara lain: (1) sentralisasi, desentralisasi, dan (3) Kombinasi. Implementasi manajemen merupakan keterlibatan perusahaan dari strategi yang telah dibuat. Dalam hal ini strategi dalam implementasi manajemen di bagi dua, yaitu self managing strategy yang berarti implementasi CSR dilakukan oleh perusahaan sendiri, dari sejak merumuskan, melaksanakan ke lapangan, serta melakukan monitoring. Dan outsourcing yaitu pelaksanaan CSR diserahkan pada pihak ketiga, perusahaan tidak terlibat langsung dalam pelaksanaan di lapangan.
Pada tahap evaluasi terhadap implementasi program SCR, PT. Astra Internasional Tbk. Hanya berdasarkan kepada standar atau norma ketercapaian itu saja, dan belum mengevaluasi atau menetapkan ukuran keberhasilan program SCR berdasrkan indikator internal dan indikator eksternal.

\section{METODE PENELITIAN}

Penelitian ini digiring paradigma positivisme, dimana dalam mengungkap masalah penelitian, peneliti terlebih dahulu membangun masalah penelitian melalui suatu konsep dan segala proses analisa juga dikaitkan kepada konsep tersebut. Dengan demikian pendekatannya adalah kualitatif. Hubungan paradigma positivisme dengan pendekatan kualitatif merujuk kepada pendapat Bungin, bahwa pendekatan kualitatif selain didasari oleh filsafat fenomelogis dan humanistis, juga mendasari pendekatannya pada filsafat lainnya, seperti empiris, idealisme, kritisme, vitalisme, dan rasionalisme maupun humanisme (Bungin, 2011).

Penelitian ini menggunakan penelitian metode deskriptif, yaitu suatu metode penelitian mengenai status kelompok manusia, suatu objek, suatu kondisi, suatu sistem pemikiran, ataupun suatu kelas peristiwa pada masa 
sekarang. Dengan metode deskriptif, peneliti melakukan pencarian atau pengumpulan data melalui wawancara dan menginterpretasikannya.

Penelitian ini dilakukan di PT. Astra International Tbk. Biz Center Bandung, J1. Soekarno Hatta No. 399, Bandung 40265, Jawa Barat - Indonesia. Dalam penelitian ini yang menjadi informan adalah orang - orang pilihan peneliti yang memiliki pengetahuan tentang apapun yang bersangkutan dengan pengalaman yang dimiliki informan. Sehingga informan dapat memberikan informasi yang dibutuhkan peneliti. Informan yang diambil dari penelitian ini adalah Divisi yang berkaitan dengan CSR Kampung Berseri. Astra.

Data yang diperoleh dari lapangan dilakukan analisis melalui tahap - tahap sebagai berikut (1) Reduksi data (data reduction) yaitu kategorisasi dan mereduksi data, dan melakukan pengumpulan terhadap informasi penting yang terkait dengan masalah penelitian, selanjutnya data dikelompokkan sesuai topik masalah. (2) Pengumpulan data (data collection) yaitu data yang dikelompokkan selanjutnya disusun dalam bentuk narasi, sehingga berbentuk rangkaian informasi yang bermakna sesuai dengan masalah penelitian. (3) Penyajian data (data display) yaitu menginterpretasikan apa yang telah diinterpretasikan informan terhadap masalah yang diteliti. (4) Penarikan kesimpulan (conclusion drawing/verification) yaitu pengambilan kesimpulan berdasarkan susunan narasi yang telah disusun pada tahap ketiga, sehingga dapat memberi jawaban atas masalah penelitian. Dan (5) Evaluasi yaitu melakukan verifikasi hasil analisis data dengan informan, yang didasarkan pada kesimpulan tahap keempat. Tahap ini dimaksudkan untuk menghindari kesalahan interpretasi dari hasil wawancara dengan sejumlah informan yang dapat mengaburkan makna persoalan sebenarnya dari fokus penelitian.

Uji keabsahan data dalam penelitian kualitatif meliputi beberapa pengujian. Peneliti menggunakan uji credibility (validitas interbal) atau uji kepercayaan terhadap hasil penelitian. Uji keabsahan data ini diperlukan untuk menentukan valid atau tidaknya suatu temuan atau data yang dilaporkan peneliti dengan apa yang terjadi sesungguhnya di lapangan. Ada beberapa cara untuk meningkatkan kredibilitas data terhadap data hasil penelitian antara lain perpanjangan pengamatan, peningkatan ketekunan 
dalam penelitian, triangulasi, diskusi dengan teman sejawat, analisis kasus negatif, dan membercheck (Satori \& Komariah, 2010).

\section{HASIL DAN PEMBAHASAN}

Perencanaan Corporate Social Responsibility PT. Astra International Tbk. melalui program Lingkungan Kampung Beseri Astra (KBA), yaitu Pertama, menetapkan visi CSR untuk Kampung Berseri Astra. Program KBA yang dibuat oleh PT. Astra International Tbk.merupakan penjabaran dari visi utama perusahaan, maka Kampung Berseri Astra sebagai salah satu CSR PT. Astra International Tbk. telah mewujudkan visi yang dibangun oleh perusahaan. Kemudian juga dipandu oleh Buku Panduan CSR yang dirumuskan dalam pedoman AFC ( Astra Friendly Company).

Berdasarkan bagan 1, maka visi KBA sejalan dengan visi perusahaan. Program CSR KBA sebetulnya tidak memiliki visi khusus dalam penetapannya, karena seluruh visi program CSR yang dilakukan oleh PT. Astra International Tbk. sejalan dengan visi perusahaan. Oleh sebab itu, KBA telah mewujudkan visi yang dibangun oleh perusahaan. Visi PT. Astra International Tbk. juga telah memberikan arahan bagi para pihak pengelola perusahaan untuk menentukan code of conduct atau kebijakan perusahaan.

Kedua, menetapkan misi CSR untuk KBA. Dalam menetapkan misi CSR, PT. Astra International Tbk. juga mengacu pada misi perusahaan serta filosofi catur dharma, yang tertuang pada point - point Catur Dharma Philosophy yaitu (1) To be an Asset to the Nation; (2) To Provide the Best Service to Our Customers; (3) To Respect Individuals and Promote Teamwork; (4) To Continually Strive for Excellence (Sustainability Report PT. Astra International Tbk. 2017). Dari poin poin tersebut dapat dilihat bahwa PT. Astra International Tbk. memiliki misi untuk memberikan nilai yang terbaik bagi bangsa dan negara, serta memfasilitasi kebutuhan masyarakat.

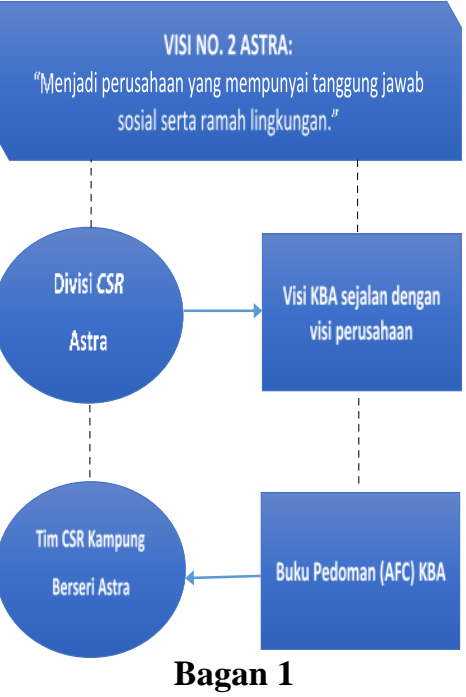

Model Proses Penetapan Visi CSR KBA Sumber: Hasil Penelitian, 2019 


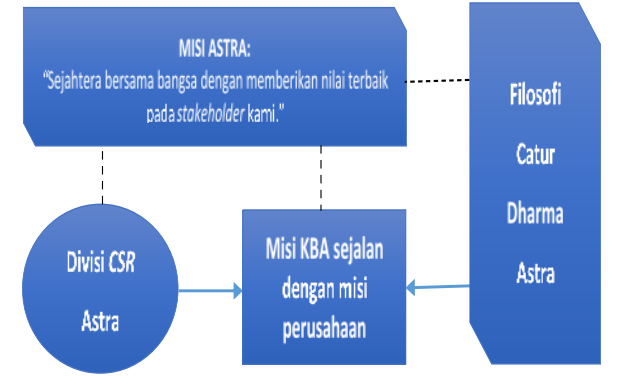

Bagan 2.

Model Proses Penetapan Misi CSR KBA Sumber: Hasil Penelitian, 2019

Berdasarkan keterangan tersebut, PT. Astra International Tbk. memiliki misi yang mampu menjabarkan secara operasional visinya. Dengan adanya landasan filosofis perusahaan, PT. Astra International Tbk. juga berupaya menginformasikan kepada stakeholder tentang aktivitas CSR KBA yang dilaksanakan. Filosofi yang dimiliki PT. Astra International Tbk. yaitu Catur Dharma juga salah satu yang berkaitan dengan misi, sehingga perusahaan menginformasikan kepada stakeholder bahwa misi tersebut berlandaskan filosofi perusahaan. Maka dari itu, CSR Kampung Berseri Astra memiliki sinergitas dengan landasan filosofis perusahaan. (Ketiga, menetapkan Tujuan CSR Kampung Berseri Astra, merumuskan tujuan dalam melaksanakan program CSR pada PT. Astra International Tbk. dilakukan oleh departemen Communications, Social Responsibility \& Security (CSRS).

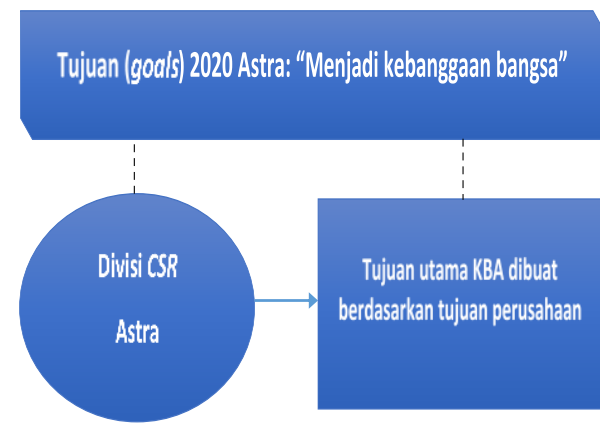

Bagan 3.

Model Proses Penetapan Tujuan CSR KBA Sumber: Hasil Penelitian, 2019

Berdasarkan keterangan tersebut, PT. Astra International Tbk. memiliki standar untuk ketercapaian segala aktivitas di perusahaan terhadap masyarakat dengan merumuskan tujuan CSR KBA secara khusus sebagai indikator penilaian. Menurut Hadi, tujuan merupakan scope hasil akhir (result) yang dicapai perusahaan sebagaimana tertuang dalam perencanaan. Penetuan tujuan penting dalam banyak aktivitas meskipun belum dilakukan, mengingat penentuan tujuan secara akurat dapat menjadi bingkai (frame) dalam segala tindakan yang akan dilakukan, dan sekaligus dapat dijadikan standar ketercapaian satu aktivitas (Hadi, 2011)

Keempat, menetapkan target CSR KBA, target digunakan oleh perusahaan sebagai batas dan acuan ketercapaian pekerjaan dari tujuan yang telah ditetapkan. Dengan adanya target jangka 
pendek dan jangka panjang, maka menjadi sebuah pengawasan perusahaan terhadap pelaksanaan CSR. Untuk menetapkan target jangka pendek dalam melaksanakan program $C S R$ pada PT. Astra International Tbk. dilakukan dengan mengacu pada form khusus yang diberikan khusus dari departemen Communications, Social Responsibility \& Security (CSRC).

Berdasarkan hasil tersebut cara menetapkan target terbagi menjadi dua, yaitu target jangka panjang yang mencakup seluruh program CSR PT. Astra International Tbk. Sedangkan target jangka pendek lebih khusus mencakup program - program CSR. Salah satunya yaitu Kampung Berseri Astra, target yang ditetapkan oleh perusahaan yaitu tampak pada bagan 4 .

Target merupakan batas dan acuan ketercapaian pekerjaan jangka pendek dari tujuan yang telah ditetapkan sebelumnya. Target penting ditetapkan, karena menjadi pengawasan pelaksanaan dan evaluasi secara melekat dari serentetan tindakan jangka waktu yang lebih lama. Dengan penetapan target, para pelaksana tanggung jawab sosial, memiliki patokan dalam melaksanakan program bersangkutan

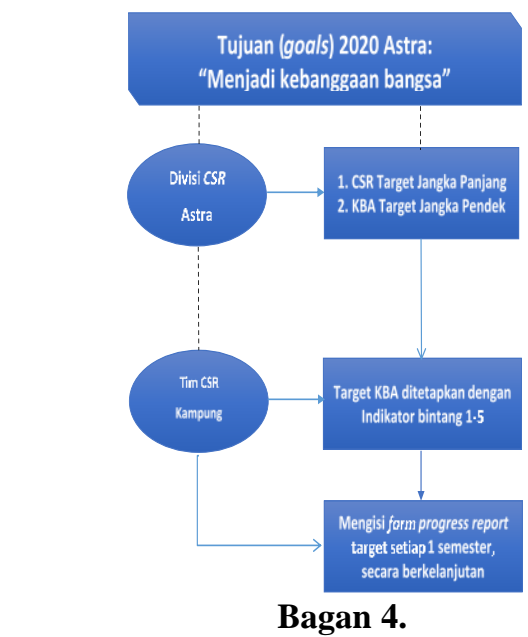

Model Proses Penetapan Target CSR KBA Sumber: Hasil Penelitian, 2019

Dari gambar tersebut dapat dilihat PT. Astra International Tbk. menetapkan indikator penilaian KBA dengan bintang 1 sampai dengan 5 sesuai potensi daerah dan 4 pilar PT. Astra International Tbk., yaitu pendidikan, lingkungan, kesehatan, dan UMKM. Kemudian untuk mengukur pencapaian bintang tersebut, disediakan form sebagai progress report selama satu semester sekali secara berkelanjutan.

Sementara itu berdasarkan keterangan gambar 1. tersebut, menunjukkan target yang ditetapkan oleh PT. Astra International Tbk. sesuai dengan pelaksanaan CSR. Dengan adanya target yang dilakukan setiap satu semester sekali, maka ini menjadi sebuah pengawasan rutin perusahaan terhadap pelaksanaan CSR.

Kelima, dalam hal menetapkan kebijakan yang digunakan CSR untuk Kampung Berseri Astra, perusahaan 
atau organisasi tentunya memiliki pedoman dalam merumuskan dan melaksanakan program CSR. Kebijakannya telah ditetapkan dalam CSRC corporate policy, poin-poinnya adalah sebagai berikut ; (1) Implementasi Astra Friendly Company (AFC) dengan target minimal bintang 4; (2) Memastikan spektrum penyebaran implementasi program - program CSR Astra di setiap provinsi; (3) Program CSR yang dilakukan perlu dioptimalkan melalui kerja sama dengan berbagai pihak seperti: pemerintah daerah, akademisi, asosiasi, komunitas sosial, dan institusi lainnya agar dampak program semakin luas;

Pengembangan inovasi program 4 pilar CSR Astra yang sejalan dengan hasil pemetaan sosial, dampak proses bisnis, dan Public Contribution Roadmap 2020 dengan fokus program pada: (i) Pilar Pendidikan, pembinaan dan peningkatan kualitas Pendidikan Anak Usia Dini dan Pengembangan program Indonesia Ayo Aman Berlalu Lintas (ii) Pilar Kewirausahaan, pemberdayaan ekonomi masyarakat (iii) Pilar Lingkungan, pengembangan Astra Forest (iv) Pilar Kesehatan (Sustainability Report 2017 PT. Astra International Tbk.). Oleh karena itu, program CSR harus terintegrasi ke dalam semua aspek dari sistem kerja perusahaan.

Pedoman PT. Astra International Tbk. yaitu mengharuskan untuk memberi laporan tertulis yang ditujukan untuk pemerintah dan publik melalui pemaparan laporan sustainalibity report. Dari kebijakan tersebut kemudian dibentuk Kampung Berseri (Bersih, Sehat, Cerdas dan Produktif) Astra. 


\section{TINGKATAN PENGEMBANGAN KAMPUNG BERSERI ASTRA}

Pengembangan Kampung Berseri Astra dapat digambarkan kedalam beberapa tahapan, dan di masing-masing tahapan terdapat target sehingga nantinya tercapai tujuan akhir dari program Kampung Berseri Astra. Secara garis besar skenario pengembangan adalah sebagai berikut:

\begin{tabular}{|c|c|c|c|c|c|}
\hline 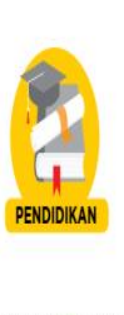 & $\begin{array}{l}\cdot<80 \% \text { masyarakat } \\
\text { bebas buta } \\
\text { aksara. } \\
\text { - Angka partisipasi } \\
\text { usia sekolah } \\
<70 \%\end{array}$ & $\begin{array}{l}\text { - } 81 \% \text {-85\% } \\
\text { masyarakat KBA } \\
\text { bebas buta aksara. } \\
\text { - Angka partisipasi } \\
\text { usia sekolah: } 71 \% \text {. } \\
75 \%\end{array}$ & $\begin{array}{l}\text { - } 86 \%=90 \% \\
\text { masyarakat KBA } \\
\text { bebas buta aksara. } \\
\text { - Angka partisipasi } \\
\text { usia sekolah: } 76 \% \text {. } \\
80 \% \\
\text { - Prestasi pendidkan } \\
\text { level kota/ } \\
\text { kabupaten. }\end{array}$ & 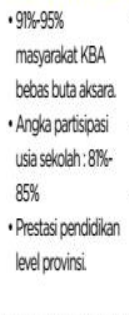 & $\begin{array}{l}\text { - P96\% masyarakat } \\
\text { KBA bebas buta } \\
\text { aksora. } \\
\text { - Angka partisipasi } \\
\text { usia sekolath >85\% } \\
\text { - Prestasi pendólikan } \\
\text { level nasional. }\end{array}$ \\
\hline WIRAUSAHAAN & $\begin{array}{l}\text { - Jumlah } \\
\text { masyarakat yang } \\
\text { terlibat dalam } \\
\text { usaha kelompok } \\
<10 \text { Orang. } \\
\text { - Peningkatan } \\
\text { jumlah } \\
\text { pendapatan } \\
\text { anggota } \\
\text { kelompok usaha } \\
<15 \%\end{array}$ & $\begin{array}{l}\text { - Jumlah } \\
\text { masyarakat } \\
\text { yang terilibat } \\
\text { dalam usaha } \\
\text { kelompok } 11 \cdot 15 \\
\text { orang. } \\
\text { - Peningkatan } \\
\text { jumlah } \\
\text { pendapatan } \\
\text { anggota } \\
\text { kelompok usaha } \\
16 \%-20 \% \text {. }\end{array}$ & $\begin{array}{l}\text { - Jumlah } \\
\text { masyarakat yang } \\
\text { terlibat dalam } \\
\text { usaha kelompok } \\
16-20 \text { orang. } \\
\text { - Peningkatan } \\
\text { jumlah } \\
\text { pendapatan } \\
\text { anggota } \\
\text { kelompok usaha } \\
21 \% \text {-24\%. } \\
\text { - Inisiasi } \\
\text { pembentukan } \\
\text { koperasi. }\end{array}$ & $\begin{array}{l}\text { - Jumlah } \\
\text { masyarakat yang } \\
\text { terlibat dalam } \\
\text { usaha kelompok } \\
21-25 \text { orang. } \\
\text { - Peningkatan } \\
\text { jumlah } \\
\text { pendapatan } \\
\text { anggota } \\
\text { kelompok usaha } \\
25 \%-30 \% \text {. } \\
\text { - Pembinaan \& } \\
\text { pengembangan } \\
\text { rintisan koperasi. }\end{array}$ & $\begin{array}{l}\text { - Jumlah } \\
\text { masyarakat yang } \\
\text { terlibat dalam } \\
\text { usaha kelompok } \\
>26 \text { orang. } \\
\text { - Peningkatan } \\
\text { jumlah } \\
\text { pendapatan } \\
\text { anggota } \\
\text { kelompok usaha } \\
>31 \% \\
\text { - Koperasi primer. }\end{array}$ \\
\hline & $\begin{array}{l}\text { - I zona } \\
\text { penghijauan } \\
\text { lingkungan. } \\
\text { - } 5 \text { orang kader } \\
\text { lingkungan. }\end{array}$ & $\begin{array}{l}\text {-2 zona } \\
\text { penghijauan } \\
\text { lingkungan. } \\
.6 .8 \text { orang kader } \\
\text { lingkungan. }\end{array}$ & $\begin{array}{l}\text {-3 zona } \\
\text { penghijauan } \\
\text { lingkungan. } \\
\cdot 9 \cdot 12 \text { orang kader } \\
\text { lingkungan. } \\
\text { - Prestasi } \\
\text { lingkungan level } \\
\text { kota/kabupaten. }\end{array}$ & $\begin{array}{l}\text {-4 zona } \\
\text { penghijauan } \\
\text { lingkungan. } \\
.13-15 \text { orang kader } \\
\text { lingkungan. } \\
\text { - Prestasi } \\
\text { lingkungan level } \\
\text { provinsi. }\end{array}$ & $\begin{array}{l}\text {-5 zona } \\
\text { penghijauan } \\
\text { lingkungan. } \\
\text {. } 16 \text { orang kader } \\
\text { lingkungan. } \\
\text { - Prestasi } \\
\text { lingkungan level } \\
\text { nasional. }\end{array}$ \\
\hline KESEHATAN & $\begin{array}{l}\text { - }<70 \% \text { masyarakat } \\
\text { bebas gizi buruk. } \\
\text { - Posyandu tingkat } \\
\text { pratama } \\
\text { - Pembinaan PHBS } \\
\text { kepada <35\% } \\
\text { rumah tangga. }\end{array}$ & $\begin{array}{l}\text { - } 71 \% \text { - } 75 \% \\
\text { masyarakat } \\
\text { bebas gizi buruk. } \\
\text { - Posyandu tingkat } \\
\text { madya. } \\
\text { - Pembinaan PHBS } \\
\text { kepada 36\%-50\% } \\
\text { rumah tangga. }\end{array}$ & $\begin{array}{l}\text {-75\%-80\% } \\
\text { masyarakat } \\
\text { bebas gizi buruk. } \\
\text { - Posyandu tingkat } \\
\text { purnama. } \\
\text { - Pembinaan PHBS } \\
\text { kepada } 51 \%-65 \% \\
\text { rumah tangga. }\end{array}$ & $\begin{array}{l}\text { - } 81 \% \text {-85\% } \\
\text { masyarakat } \\
\text { bebas gizi buruk. } \\
\text { - Posyandu tingkat } \\
\text { mandiri. } \\
\text { - Pembinaan PHBS } \\
\text { kepada 66\%-75\% } \\
\text { rumah tangga. }\end{array}$ & $\begin{array}{l}\text { - >85\% masyarakat } \\
\text { bebas gizi buruk. } \\
\text { - Posyandu tingkat } \\
\text { mandiri plus. } \\
\text { - Pembinaan PHBS } \\
\text { kepada } 75 \% \\
\text { rumah tangga. }\end{array}$ \\
\hline
\end{tabular}

Gambar 1.

Target CSR KBA PT. PT. Astra

International Tbk.

Sumber: Sustainability Report 2017

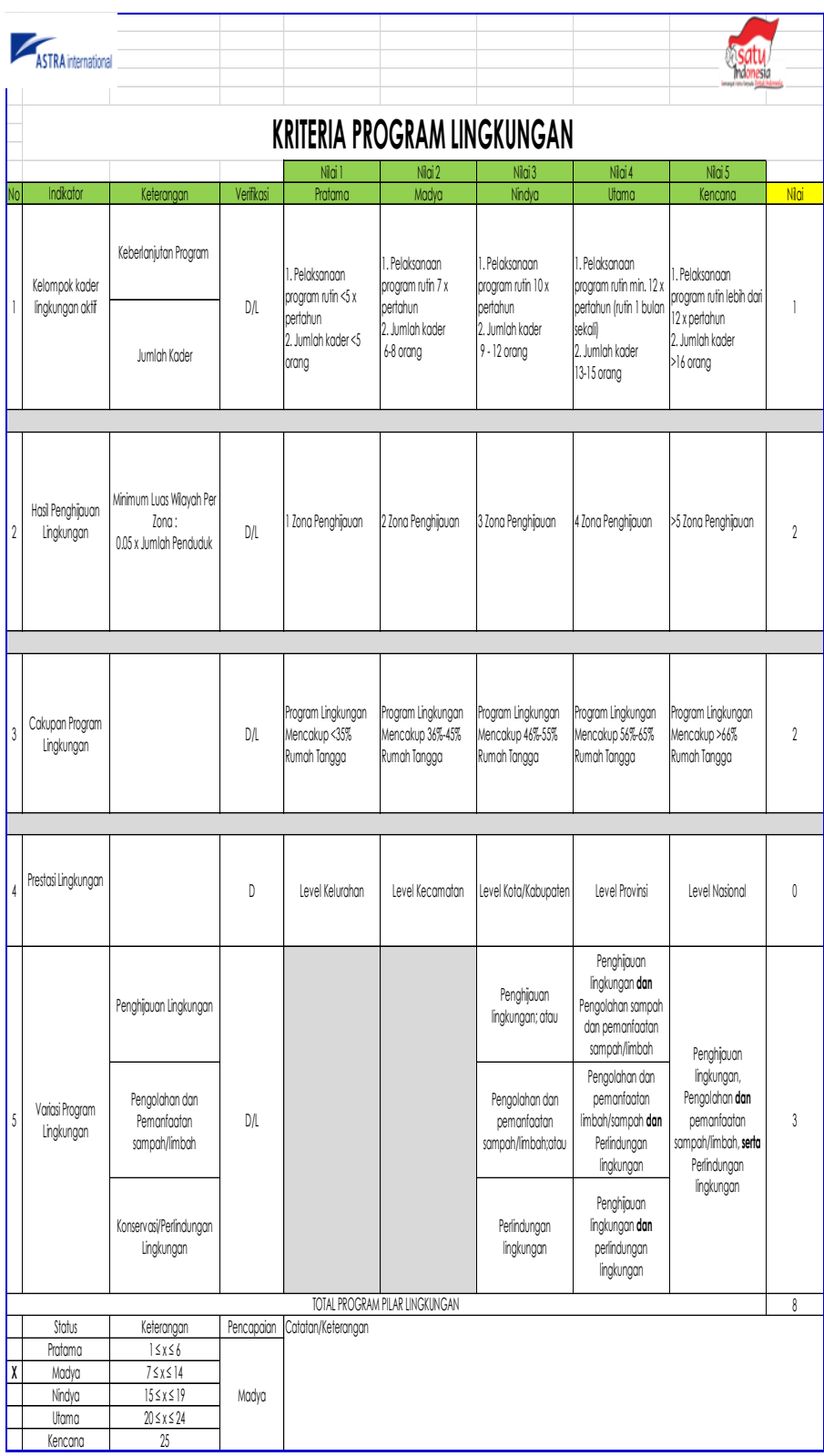

Gambar 2.

Form progress report CSR Lingkungan KBA Sumber: Data PT. Astra International Tbk. Biz Center Bandung 2018

JURNAL SIGNAL Volume 8, No. 2, Juli 2020, hlm 89-214| Ilmu Komunikasi - FISIP 


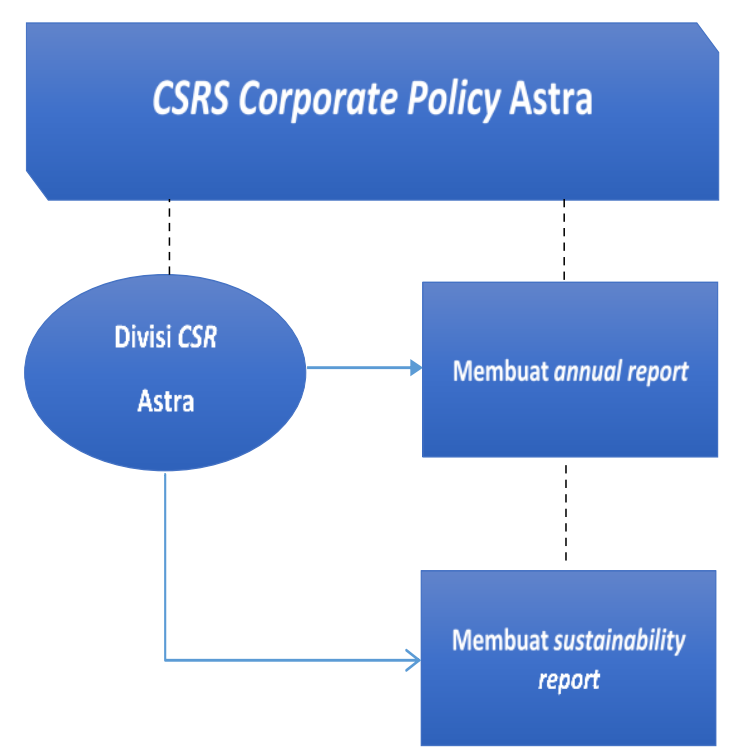

Bagan 5.

Model Proses Penetapan Kebijakan CSR KBA

Sumber: Hasil Penelitian, 2019

Dari bagan 5 tersebut, kebijakan yang ditetapkan oleh KBA tertuang pada pedoman Astra Friendly Company (AFC), karena PT. Astra International Tbk. merupakan perusahaan terbuka, maka setiap tahun PT. Astra International Tbk. membuat annual dan sustainability report. Laporan tersebut ditujukan untuk pemangku kepentingan dan publik. Contohnya seperti tampak pada gambar berikut:

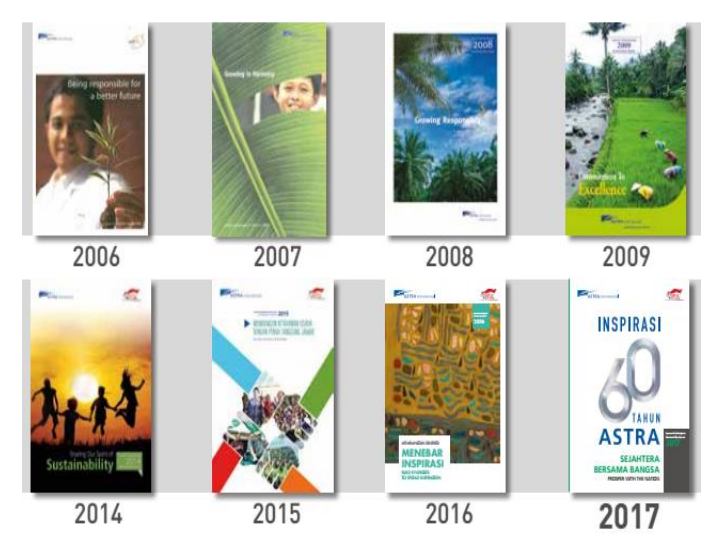

Gambar 3.

Suistainability report PT. Astra International Tbk.

Sumber: PT. Astra International Tbk.co.id

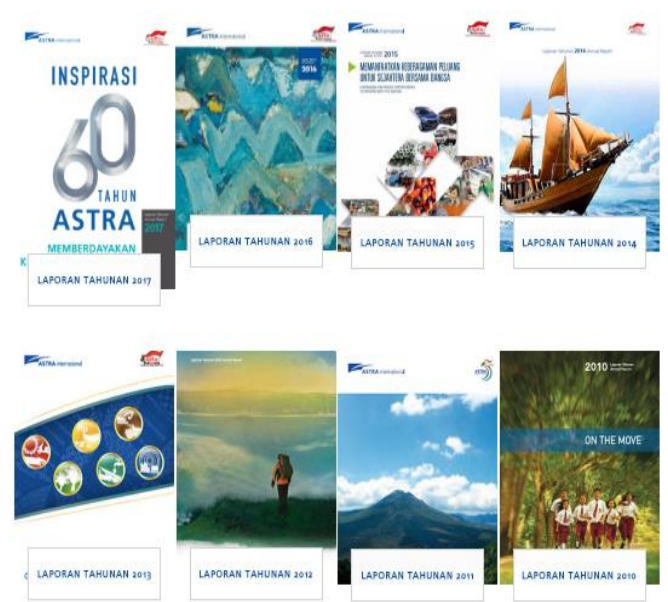

Gambar 4.

Annual report PT. Astra International Tbk Sumber: PT. Astra International Tbk.co.id

Keenam, menetapkan strategi CSR untuk Kampung Berseri Astra. Dalam menetapkan strategi CSR yang dilakukan oleh PT. Astra International Tbk. untuk program KBA dilakukan dengan mengacu pada triple-p roadmap, yakni (1) Portofolio Roadmap untuk meningkatkan nilai bagi pemegang saham, (2) People Roadmap dalam rangka membangun Insan Astra yang kompeten dan kompetitif, (3) Public Contribution Roadmap, yaitu memberikan manfaat melalui pengelolaan lingkungan, keselamatan dan kesehatan kerja di seluruh instalasi Astra, serta mewujudkan tanggung jawab sosial ke tengah masyarakat. Dan langkah selanjutnya perusahaan 
membangun komunikasi dengan publik yang terkait dengan KBA untuk bekerjasama dalam perencanaan program ini.

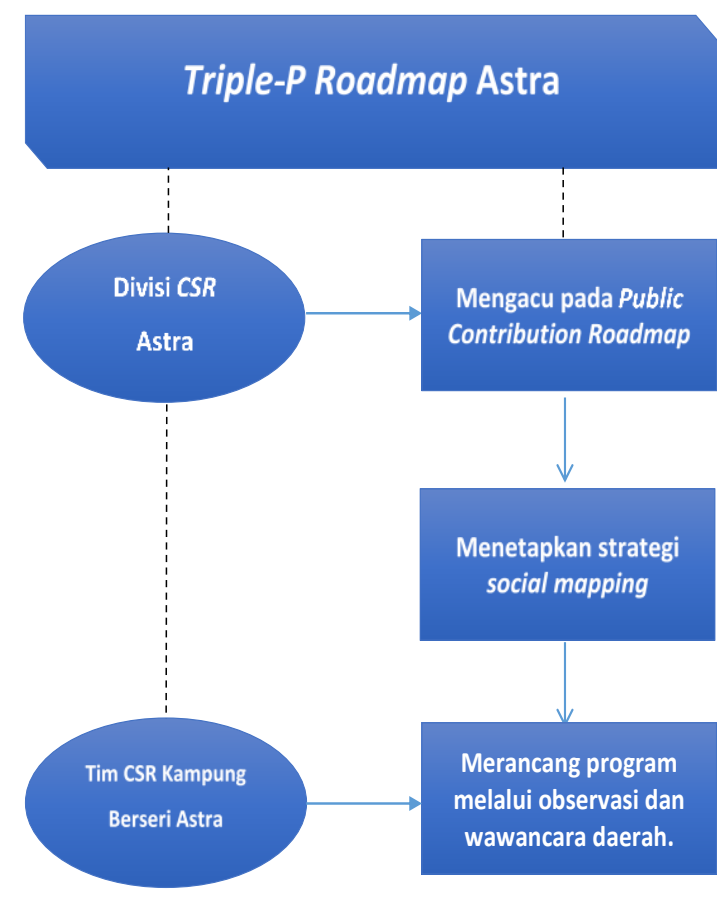

\section{Bagan 6. \\ Model Proses Penetapan Strategi CSR KBA Sumber: Hasil Penelitian, 2019}

Dalam hasil triangulasi dengan Perdana G. Putra sebagai EHS \& CSR Analyst PT. Astra International Tbk. menjelaskan bahwa Strategi dalam menjalankan program KBA dengan melakukan social mapping para stakeholder dan pihak lain yang terlibat, baik internal dan juga eksternal. Melakukan komunikasi dengan pemerintah yang terkait, untuk memudahkan jalannya pelaksanaan program KBA. Tujuan dilakukan komunikasi dengan pemerintah, agar menjaga hubungan baik dan mengurangi resiko terjadinya dampak negatif dalam perencanaan hingga pelaksanaan.

Ketujuh, menetapkan rancangan struktur organisasi $C S R$ yang digunakan untuk Kampung Berseri Astra. Dalam rangka menjaga pelaksanaan $C S R$ Kampung Berseri Astra, perusahaan melakukannya secara serius dan terencana. Dengan membentuk suatu susunan yang khusus dari pusat hingga ke lapangan, agar mampu dipertanggung jawabkan atas pelaksanaannya.

Berdasarkan bagan 7. diketahui bahwa, dengan mendirikan divisi Corporate Communications, Social Responsibilyt, \& Security dan membentuk tim khusus dalam perencanaan CSR KBA. Maka PT. Astra International Tbk. telah melakukan CSR Kampung Berseri Astra secara serius dan terencana, guna menjaga pelaksanaannya agar mampu dipertanggung jawabkan.

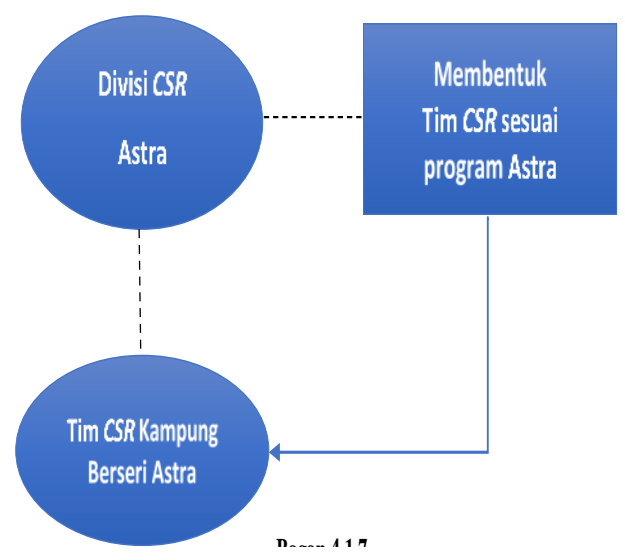




\section{Bagan 7.}

Model Proses Penetapan Struktur Organisasi CSR KBA

Sumber: Hasil Penelitian, 2019

Ketujuh, menetapkan rancangan program CSR untuk Kampung Berseri Astra. Perancangan program CSR KBA, Divisi Social Responsibility PT. Astra International Tbk. berperan sebagai inisiator namun program tersebut dan dirumuskan secara bersama - sama melalui proses diskusi dengan top level management. Pada perumusan program CSR KBA, top level management berperan untuk menilai kesesuaian program yang dilakukan dengan visi perusahaan.

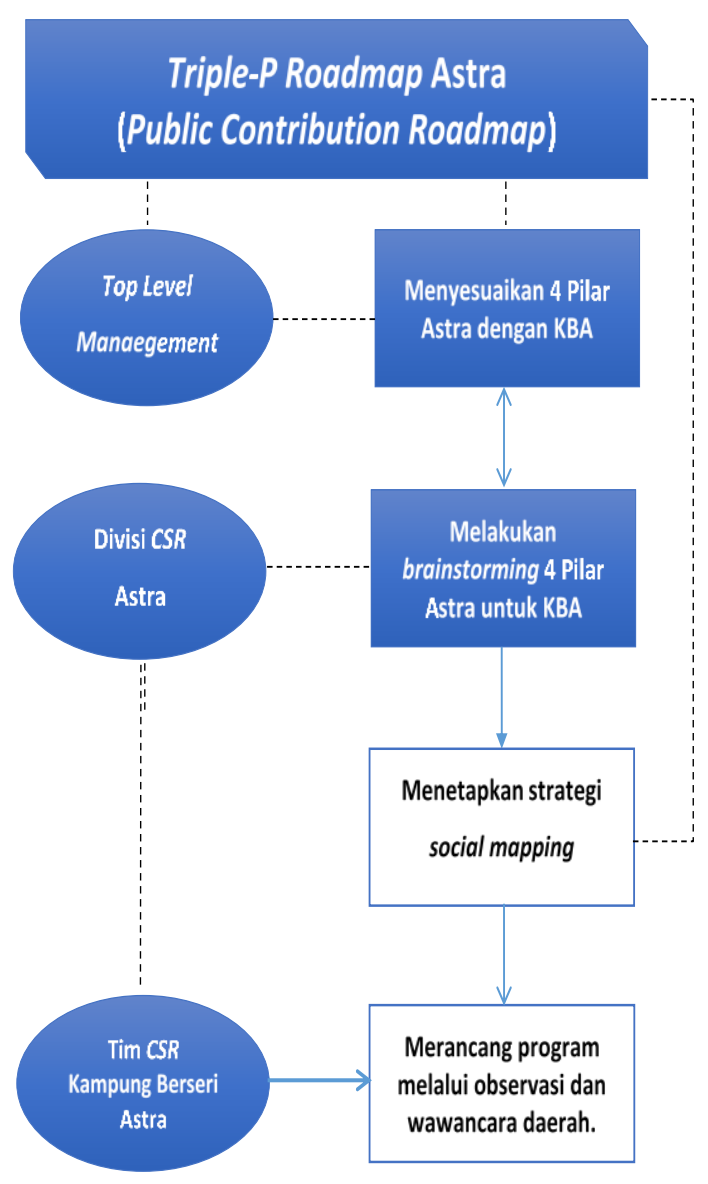

\section{Bagan 8. \\ Model Proses Penetapan Rancangan Program CSR KBA \\ Sumber: Hasil Penelitian, 2019}

Dari bagan tersebut diketahui bahwa perancangan program $C S R \mathrm{KBA}$, Divisi Social Responsibility PT. Astra International Tbk. berperan sebagai inisiator namun program tersebut dan dirumuskan secara bersama - sama melalui proses diskusi dengan top level management. Setelah semuanya matang, baru rancangan program KBA dieksekusi ke wilayah dimana PT. Astra International Tbk. didirikan. Di desa dilakukan koordinasi kembali dengan 
ketua RW dan tokoh masyarakat. Dalam koordinasi tersebut pun dilakukan juga rancangan program yang sesuai dengan catur dharma dan potensi di setiap daerah. Setelah ditetapkan rancangan program CSR KBA, kemudian dilanjutkan pada tahapan menyediakan SDM.

Kedelapan, menyediakan SDM untuk CSR Kampung Berseri Astra. Proses untuk menyediakan Sumber Daya Manusia (SDM) dalam program CSR untuk Kampung Berseri Astra tidak hanya melibatkan Divisi Social Responsibility, kadang juga melibatkan pihak ketiga.

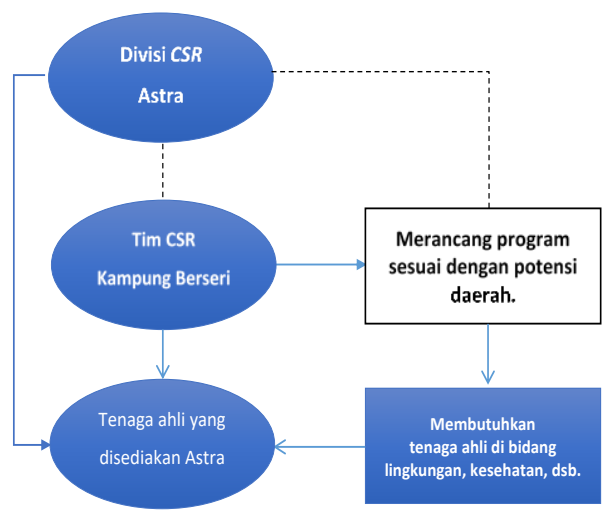

Bagan 9.

Model Proses Penetapan SDM CSR KBA Sumber: Hasil Penelitian, 2019

Berdasarkan bagan 4.1.8 tersebut, maka perusahaan telah menyiapkan SDM dengan baik. Hal ini juga dilakukan karena kolaborasi dengan pihak eksternal dapat menumbuhkan kekuatan, emphaty, melengkapi strategi dan kapabilitas yang tidak dimiliki oleh perusahaan.

Kesembilan, penggunaan linkage stakeholder untuk CSR KBA. Berdasarkan keterangan tersebut, maka PT. Astra International Tbk. telah membangun kedekatan dengan masyarakat di sekitarnya. Melibatkan pihak internal perusahaan untuk berinteraksi dengan pihak eksternal perusahaan maka membantu jalannya CSR KBA.

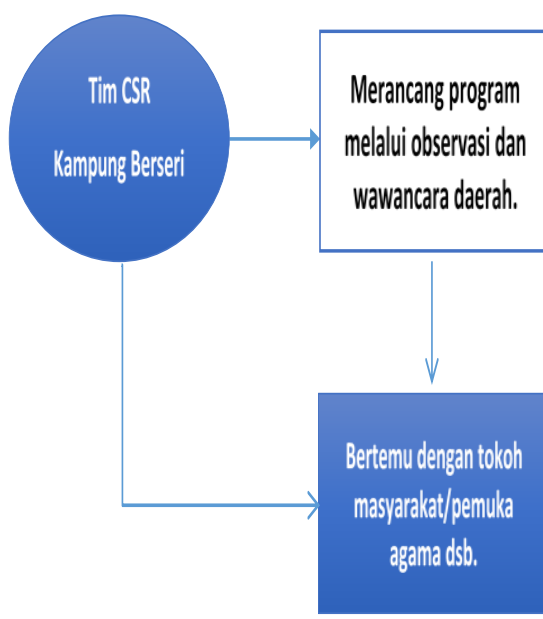

Bagan 10.

Model Proses Linkage Stakeholder CSR KBA

Sumber: Hasil Penelitian, 2019

Kemudian dilanjutkan pada tahap pemetaan wilayah.

Kesepuluh, pemetaan wilayah untuk CSR Kampung Berseri Astra memprioritaskan ring 1 (satu) serta melihat kriteria yang sesuai dengan perusahaan serta masyarakat yang berada di sekitar perusahaan. 


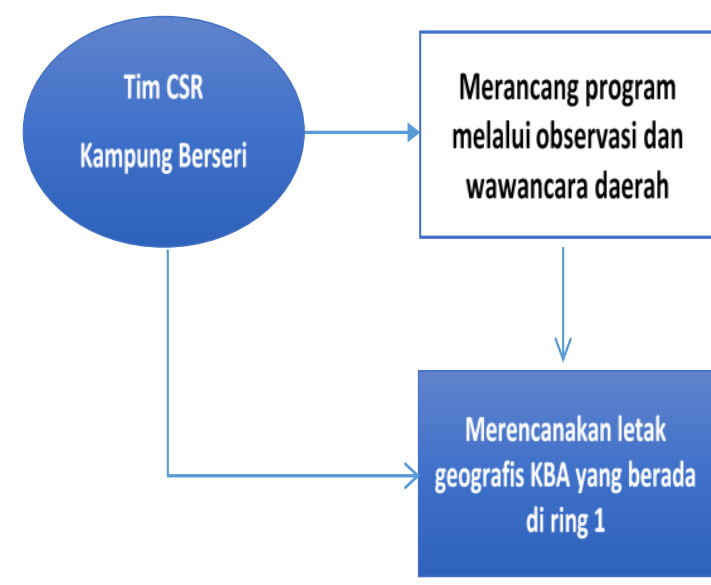

Bagan 11.

Model Proses Menetapkan Wilayah CSR KBA

Sumber: Hasil Penelitian, 2019

Pemetaan wilayah CSR KBA memiliki keterkaitan dengan linkage stakeholder dan social mapping. Karena dalam hal ini, dimanapun PT. Astra International Tbk. didirikan harus ada kontribusi nyata untuk warga. Prioritas yang dijadikan target sasaran $C S R$ KBA ini adalah desa yang jaraknya berada di ring 1. Sesuai dengan gambaran pemetaan wilayah pelaksanaan $C S R$. Pemetaan wilayah adalah skala prioritas pelaksaanaan CSR suatu daerah yang dijadikan sasaran (Hadi, 2011).

Kesebelas, penetapan sumber dana untuk $C S R$ KBA, memprioritaskan kebutuhan masyarakat setiap tahun seperti apa dengan mengacu pada 4 pilar perusahaan.

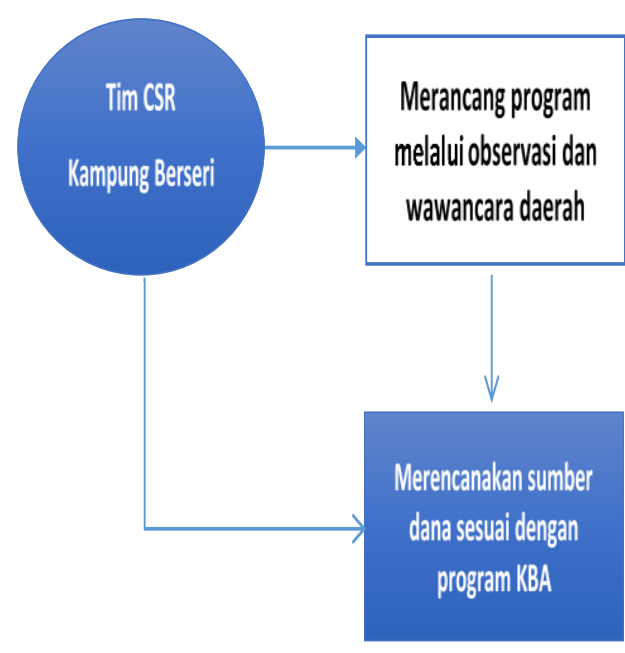

Bagan 12.

Model Proses Penetapan Sumber Dana CSR KBA

Sumber: Hasil Penelitian, 2019

Sebagaimana tampak pada bagan 12 , proses penetapan sumber dana $C S R$ untuk Kampung Berseri Astra ditentukan oleh potensi desa tersebut. Potensinya bermacam - macam dari bidang pariwisata, lingkungan, pendidikan, dll. Sehingga fungsi PIC Kampung Berseri Astra masing - masing desa juga berperan untuk memilih kesesuaian program dengan pilar perusahaan. Sehingga nantinya dana yang perusahaan keluarkan akan sejalan dengan pilar perusahaan.

Implementasi CSR PT. Astra Internationa Tbk. berdasarkan pilar atau program lingkungan berupa Kampung Beseri Astra (KBA). Dalam implementasi ini, terbagi menjadi dua yaitu mengimplementasikan program CSR Kampung Berseri Astra, dan 
mengimplementasikan manajemen $C S R$ KBA. Program CSR KBA yang dijalankan oleh perusahaan dibagi ke dalam 4 pilar. Yaitu kesehatan, pendidikan, lingkungan, dan UKM. Berdasarkan hasil social mapping, penerima program ini tersebar di 34 provinsi di Indonesia. Hingga tahun 2018 tercatat ada 72 desa yang telah menjadi Kampung Berseri PT. Astra International Tbk. (1) Implementasi Program CSR KBA, dalam implementasinya dijelaskan bahwa program KBA ini diaplikasikan oleh perusahaan melalui tim yang tersebar di masing - masing KBA, terdapat beberapa kendala teknis yang berpengaruh terhadap manajemen implementasi KBA.

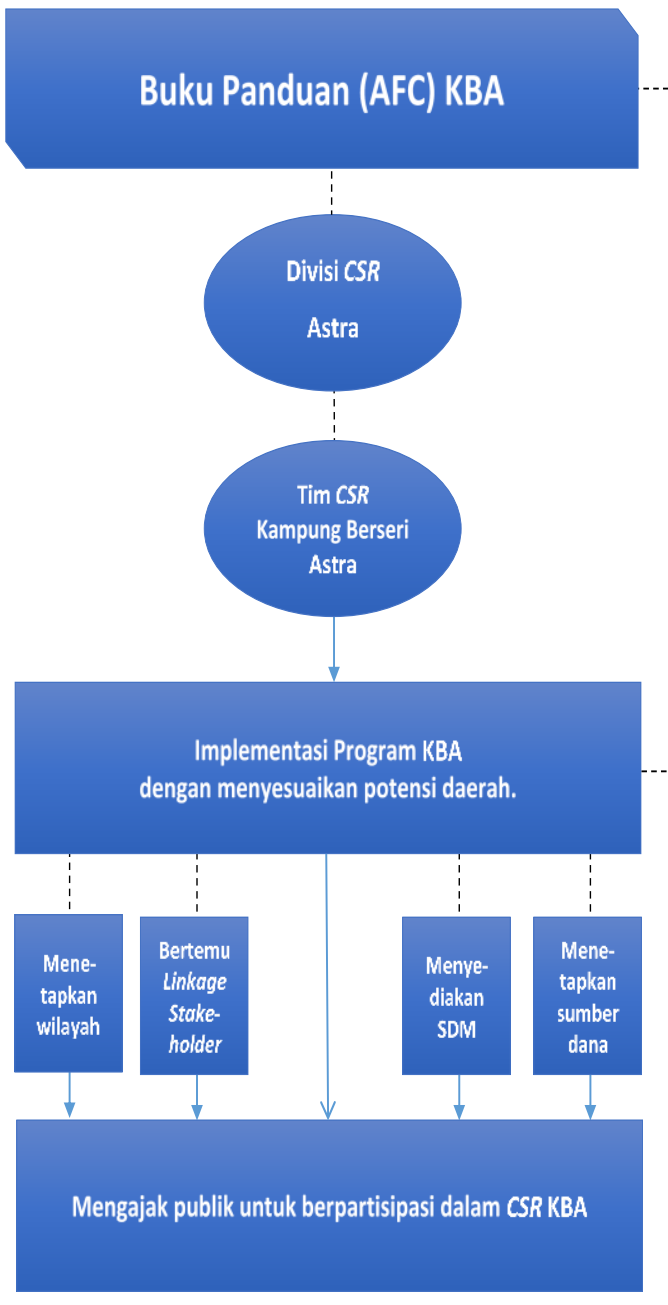

Bagan 13.

Model Proses Implementasi Program CSR KBA

Sumber: Hasil Penelitian, 2019

Dalam bagan tersebut, dapat dilihat bahwa implementasi program merupakan pelaksanaan dari strategi yang telah dibuat oleh Tim CSR KBA, dengan panduan $A F C$. Maka dalam implementasi program, CSR KBA termasuk pada strategi sentralisasi (Hadi, 2011). Karena segala program yang dilaksanakan merupakan arahan langsung dari pusat melalui media buku panduan. (2) Implementasi Manajemen 
CSR Kampung Berseri PT. Astra International Tbk., dalam implementasinya dijelaskan bahwa manajemen KBA memang melibatkan perusahaan, namun tim $C S R$ KBA yang ada dilapangan merasa memiliki kendala dalam pendampingan program.

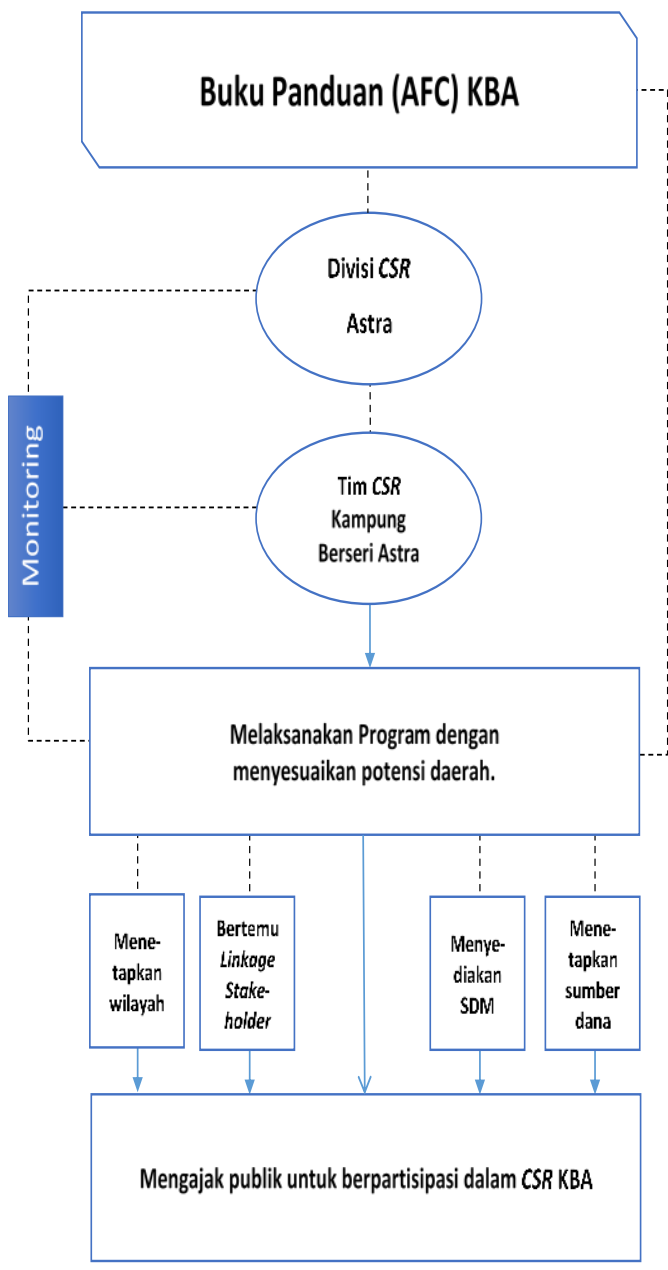

Bagan 14.

Model Proses Implementasi Manajemen CSR KBA

Sumber: Hasil Penelitian, 2019

Melihat pada bagan tersebut, maka CSR Kampung Berseri Astra termasuk pada strategi self managing (Hadi, 2011). Namun masih dalam proses untuk tahap perbaikan dalam pengawasan kegiatan. Karena beberapa desa masih butuh pembinaan yang khusus agar lebih berpotensi.

Evaluasi Corporate Social Responsibility PT. PT. Astra International Tbk., dimana program Kampung Berseri Astra dalam evaluasi ini terbagi menjadi dua, yaitu evaluasi dengan indikator internal dan evaluasi dengan indikator eksternal. Serta terdapat tingkatan pencapaian status (Bintang 1 sampai dengan 5) yang berhasil diimplementasikan dalam suatu wilayah. Tingkatan tersebut harus sesuai dengan proyeksi Kampung Binaan PT. Astra International Tbk. dalam target lima tahun yang telah ditetapkan. Evaluasi ini juga dilakukan oleh pusat serta tim CSR KBA. Salah satunya pernah diadakan satu kali festival. Selain sebagai special event, pelaksanaan ini pun digunakan sebagai evaluasi terbuka untuk seluruh desa yang ada di Indonesia.

Yang dimaksud evaluasi Indikator Internal Kampung Berseri Astra ini terbagi dalam dua tahap, yaitu ukuran primer yang mencakup kegiatan operasional perusahaan. Kemudian ukuran sekunder yang mencakup tingkat compliance pada aturan sebuah perusahaan. Dalam evaluasinya, CSR 
KBA memiliki evaluasi yang berkaitan dengan kedua ukuran tersebut. Dengan tahapan evaluasi internal tersebut, PT. Astra International Tbk. Juga memperhatikan penilaian terhadap kegiatan operasional perusahaannya. Pencapaian CSR KBA juga dijadikan acuan, agar perkembangannya dapat terpantau.

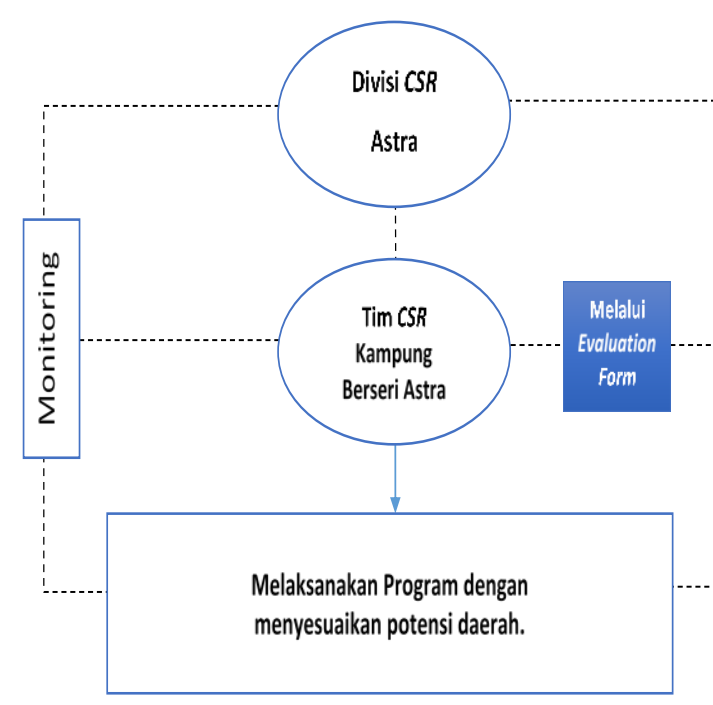

Bagan 15.

Model Proses Evaluasi Indikator Internal

CSR KBA

Sumber: Hasil Penelitian, 2019

Berdasarkan hasil dari bagan tersebut, maka evaluasi internal $C S R$ KBA memiliki evaluasi yang berkaitan dengan kedua ukuran tersebut. Evaluasi dilakukan secara bertahap, dari pusat hingga tim CSR KBA di lapangan. Dilakukan By data dengan form untuk compliance yang terkait dengan perusahaan. Seperti pada gambar berikut:

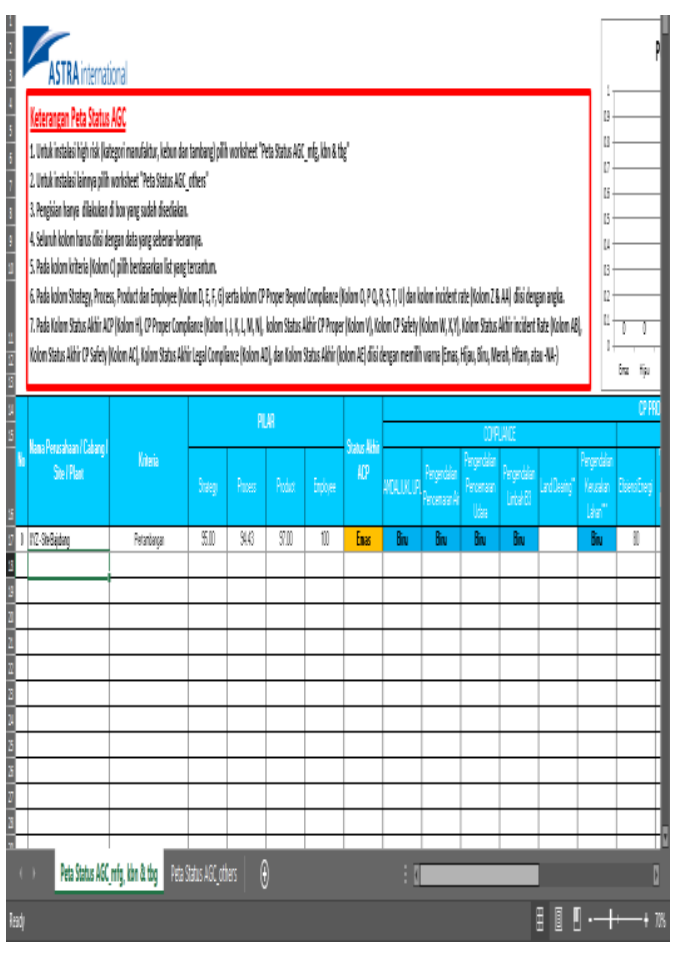

Gambar 6.

Evaluation Form AGC PT. PT. Astra International Tbk.

Sumber: Data PT. Astra International Tbk. Biz Center Bandung

Dengan tahapan evaluasi internal tersebut, PT. Astra International Tbk., juga memperhatikan penilaian terhadap kegiatan operasional perusahaannya. Pencapaian CSR Kampung Berseri Astra dijadikan acuan, agar perkembangannya dapat terpantau. Sementara itu, Evaluasi Indikator Eksternal CSR Kampung Berseri Astra, dilakukan dengan musyawarah untuk melihat kualitas hubungan sosial antara perusahaan dan masyarakat. Sementara untuk tingkat ekonomi dilakukan dengan form sebagai data perusahaan. 


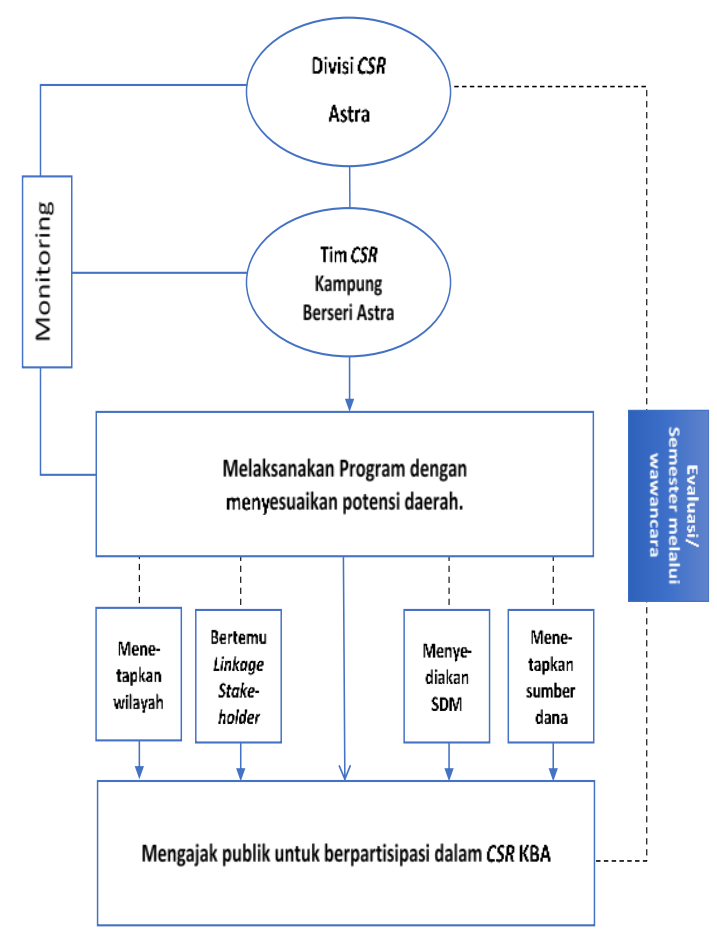

Bagan 16.

Model Proses Evaluasi Indikator Eksternal CSR KBA

Sumber: Hasil Penalitian, 2019

Berdasarkan hasil dan keterangan tersebut, maka evaluasi CSR KBA secara eksternal memiliki evaluasi yang berkaitan dengan kedua ukuran tersebut. Namun untuk indikator sosial tidak dilakukan by data melainkan dengan interaksi langsung dengan warga. Evaluasi eksternal yang dilakukan pusat ke lapangan adalah mendatangi langsung dan wawancara melalui perwakilan masyarakat. Yang disebut dengan monitoring, dan melakukan proses wawancara dengan perwakilan masyarakat tentang perkembangan KBA. Jika dari aspek ekonomi dapat dilihat by data, jika dari aspek sosial antara perusahaan dan warga lebih mendalam melalui wawancara dan musyawarah. Kegiatan tersebut juga antara lain untuk melihat kualitas hubungan sosial antara perusahaan dan masyarakat.

Dalam mengevaluasi atau mengukur tingkat ketercapaian tujuan program SCR, Kartini (2013) memerinci delapan indikator yang sebaiknya digunakan, yaitu : 1) Leadership, program SCR berhasil jika mendapatkan dukungan dari top management perusahaan dan ada kesadaran filantropi dari pimpinan yang menjadi dasar pelaksanaan program, 2) Proporsi Bantuan, CSR dirancang bukan sematamata pada kisaran anggaran saja, melainkan pada tingkatan serapan maksimal, 3) Transportasi dan akuntabilitas, terdapata laporan tahunan dan mekanisme audit sosial dan finansial, 4) Cakupan wilayah, terdapat identifikasi penerima manfaat secara tertib dan rasional berdasarkan skala prioritas yang telah ditentukan, 5) Perencaaan, mekanisme pamnatauan, dan evaluasi, 6) Pelibatan Pemangku Kepentingan, terdapat mekanisme koordinasi reguler dengan pemangku kepentingan, utamanya masyarakat dan menjamin partisipasi masyarakat untuk dapat terlibat dalam siklus proyek, 7) 
Keberlanjutan, terjadi alih peran dari korporat ke masyarakat kemudian tumbuhrasa memiliki program, 8) Hasil nyata (outcome), terjadinya perubahan pola pikir masyarakat dapat memberikan dampak ekonomi masyarakat yang dinamis dan memperkuat komunitas (Kadarisman, 2019).

\section{SIMPULAN}

Berdasarkan hasil penelitian dan pembahasan, maka dapat ditarik simpulan sebagai berikut, pada tahap perencanaan program CSR Kampung Berseri Astra mengacu pada visi dan misi utama perusahaan untuk membentuk tujuan utama programnya. . Setelah tujuan tersebut ditetapkan, maka KBA menjadi salah satu target jangka pendek perusahaan untuk mencapai tujuan utama perusahaan. Target tersebut dituangkan dalam indikator penilaian berupa bintang 1 sampai 5. Kebijakan menjadi pedoman PT. Astra International Tbk. dalam merencanakan program $C S R$, khususnya Kampung Berseri Astra. Selain tertuang dalam Coporate Policy, karena PT. Astra International Tbk. merupakan perusahaan terbuka maka salah satu kebijakannya dituangkan dalam sebuah laporan tahunan. Yaitu annual dan sustainabilty report. Laporan tersebut juga berguna bagi stakeholder dan publik.

Dalam proses menetapkan strategi, PT. Astra International Tbk. mengacu pada triple-p roadmap point ke-3 yaitu public contribution roadmap sehingga strategi yang ditetapkan berupa social mapping melalui observasi dan wawancara pada daerah yang berpotensi sebagai Kampung Berseri Astra. Kemudian secara struktur organisasi, divisi CSR membentuk kembali Tim CSR KBA secara khusus di masing masing wilayah. Agar tim tersebut dapat bertanggung jawab atas pelaksanaan program $C S R$. Tim selanjutnya merumuskan program CSR Kampung Berseri Astra. Kemudian, konsep tersebut dikomunikasikan kembali ke divisi $C S R$ untuk dilakukan penilaian mengenai kesesuaian program dengan visi, misi tujuan perusahaan juga tujuan publik.

Dalam menetapkan rancangan program dilakukan dengan memetakan wilayah yang berada di ring 1 pada setiap instalasi perusahaan PT. Astra International Tbk. di Indonesia. Kemudian melakukan komunikasi dengan masyarakat melalui tokoh atau perwakilan masyarakat yang berpengaruh, setelah itu menyediakan SDM yang ahli pada bidang tertentu. 
Penetapan sumber dana dilakukan setelah perencanaan program telah matang melalui data form yang disediakan oleh PT. Astra International Tbk..

Pada proses implementasi program, PT. Astra International Tbk. melaksanakan strategi yang telah dibuat oleh Tim CSR KBA dengan panduan AFC. Maka dalam implementasi program, CSR KBA termasuk pada strategi sentralisasi. Karena segala program yang dilaksanakan merupakan arahan langsung dari pusat melalui media buku panduan. Kemudian secara implementasi manajemen termasuk pada self-managing. Karena pada program tersebut tidak terdapat pihak ketiga yang memberikan tambahan operasional dalam pelaksanaan. Kendala yang dialami pada tahapan implementasi manajemen ini adalah kurangnya pendampingan pada tiap masing masing wilayah. Sehingga program yang sedang berjalan, ketika mengalami kendala maka akan terbengkalai hingga proses monitoring diadakan. Pada tahapan ini sedang dikembangkan kembali pengawasannya, agar setiap desa dapat berkembang sesuai dengan target yang diaharapkan.

Pada proses evaluasi, PT. Astra International Tbk. memandang program
KBA adalah sebagai peningkatan kualitas hidup masyarakat di bidang pendidikan, kesehatan, lingkungan, dan UMKM. Maka setiap 1 semester sekali diadakan monitoring dan progress report melalui form yang telah dibuat. Kemudian evaluasi terhadap image dan hubungan sosial perusahaan juga dilakukan dengan mewawancarai langsung masyarakat yang tekait dengan program Kampung Berseri Astra. Sehingga jika dimasukan dalam evaluasi kategori internal dan eksternal, PT. Astra International Tbk. telah melakukan evaluasi tersebut dengan teknis yang mereka miliki. Meskipun pada tahun 2018 program ini belum mencapai target sepenuhnya, namun program $C S R$ Kampung Berseri Astra telah memperoleh apresiasi yang baik dari 72 wilayah di Indonesia, karena jika perusahaan mendapat apresiasi yang kurang berkenan maka program tersebut jumlahnya akan berkurang. Dengan demikian PT. Astra International Tbk. berkomitmen untuk terus melakukan evaluasi baik evaluasi keberhasilan maupun evaluasi permasalahan permasalahan dan kendala yang dihadapi dalam pelaksanaannya, sehingga dapat dilakukan perbaikan dan pengembangan program tersebut. 
Saran dalam tahap perencanaan program CSR KBA, PT. Astra International Tbk.agar dapat mempertahankan berjalannya program Kampung Berseri Astra. Karena hampir dalam seluruh proses perencanaan, PT. Astra International Tbk. telah melakukannya dengan baik dan berkesinambungan dengan konsep tahapan CSR dari Nor Hadi. Dalam pelaksanaan program $C S R$ KBA, PT. Astra International Tbk. adalah, melakukan pendampingan khusus di masing - masing daerah Kampung Berseri Astra. Karena dalam pelaksanaannya, PIC yang ditugaskan menjembatani masyarakat dengan pusat juga memiliki jabatan lain di perusahaannya. Sedangkan, untuk program yang diadakan secara berkelanjutan dan melibatkan publik esksternal, pengawasannya harus diadakan lebih rutin. Hal ini dikarenakan beberapa wilayah di Indonesia memiliki potensi yang berbeda, sehingga dalam pelaksanaannya memiliki tingkat heterogensi yang cukup tinggi. Pada proses evaluasi pun berkaitan dengan proses pendampingan dalam pelaksanaan. Harusnya perusahaan melakukan monitoring langsung ke lapangan secara berkala. Pada saat ini perusahaan cenderung lebih mengutamakan evaluasi berdasarkan data, oleh karena itu perusahaan disarankan untuk melakukan evaluasi lebih menyeluruh di masing - masing daerah. Untuk melihat sejauh mana program CSR Kampung Berseri Astra tetap stabil dalam pelaksanaannya.

\section{DAFTAR PUSTAKA}

Andriana, (., Novianti, E., Priyatna, C. C., \& Rejeki), D. S. (2019). Corporate social responsibility pada program Indonesia Digital Learning (IDL) PT. Telekomunikasi Indonesia. PRofesi HUmas, 68-95.

Bungin, B. (2011). Metodologi Penelitian Kualitatif. Jakarta: Kencana Predana Media Grup.

Hadi, N. (2011). Corporate Social Responsibility. Yogyakarta: Graha Ilmu.

Kadarisman, A. (2019). Komunikasi Lingkungan pendekatan Sustainable Development Goals (SDGs) dan Corporate Social Responsibility (CSR). Bandung: Simbiosa Rekatama Media.

Moleong, L. J. (2010). Metode Penelitian Kulitatif. Bandung: Remaja Rosdakarya.

Nugraha, A. R., Sumartias, S., Novianti, E., \& Komariah, K. (2015). Implementasi Kegiatan Corporate Social Responbility "Go Green Economic" Berbasis Kearifan Lokal. Jurnal Komunikasi, 118128.

Prastowo, J., \& Huda, M. (2011). Corporate Social Responsibility: 
Kunci meraih kemuliaan bisnis. Yogyakarta: Samudra Biru.

Rahmayani, R., \& Silvana, H. ( 2018). Program Corporate Social Responsibility (CSR) Pada PT Indocement Tunggal. PRofesi Humas: Jurnal Ilmiah Ilmu Hubungan Masyarakat, 186-202.

Rakhmat, J. (2009). Metode Penelitian Komunikasi. Bandung: Remaja Rosdakarya.

Satori, D., \& Komariah, A. (2010). Metodologi Penelitian Kualitatif. Bandung: Alfabeta, CV.

Setianto, W. A. (2012). Pola Adopsi Corporate Social Responsibility. Dalam N. Prajarto, CSR Indonesia Sinergi Pemerintah, Perusahaan, dan Publik (hal. 68). Yogyakarta: FISIP UGM.

Solihin, I. (2009). Corporate Social Responsibility: From charity to sustainability. Jakarta: Salemba.

Sugiyono. (2012). Metode Penelitian Kualitatif Kuantitatif $R \& D$. Bandung: Alfabeta. 